な結果もみうれた。読影方法に検討を要するとの答えで あった，木下は，加えてローテーションの頻繁な病院は 画質がかなり悪い傾向にあったと報告した，両者ともい くつかの興味ある結果. 引き出せるようであり，まだ解 析不足のところも見受けられ，さらに十分な検討を加え られて報告されることを期待する。

\section{RI一4. 消化器他}

\section{座長 小川1 清（埼玉医大総合医療センター）}

137. RI-angiography による慢性下肢動脈閉塞症の術 前, 術後評価法

$$
\begin{aligned}
& \text { 三木市立三木市民病院 } \\
& \text { ○平田敏辛・藤原義行 } \cdot \text { 三輪幸男 } \\
& \text { 西本公仁・吉田博义 } \cdot \text { 坂本久彰 } \\
& \text { 福川 孝 }
\end{aligned}
$$

慢性下肢動脈閉塞症の術前後評価法として, first pass RI-angiography $\left({ }^{99 m} \mathrm{Hc}-\mathrm{RBC} 20 \mathrm{mCi}\right)$ を行 分岐部上部抽よび左右両下肢動脈上に関心領域を定め, time activity curve (TAC) を求め, TACに gamma fitting 処理, 指数関数 fitting 処理, 微分処理等行い, 比較検討を行った。

これらの指標を検討した結果，左右両下肢動脈上と大 動脈分岐部上部との差, relative mean transit time ( $R$ -MTT）が自覚症状と最もよく相関し，かつ再現性がよ $く, \mathrm{R}-\mathrm{MTT}$ は術前後および術後長期間の定量的評価法 として有意義と考えられた。

138. ベッドスライド方式による末梢 RI angiography 名古屋市立大学病院中央放射線部

○竹内憲彦・石原正司・春藤英雄 柴田靖彦・岩田宏道

名古屋市立大学医学部放射線医学教室 松尾導昌

インビボ標識 Tc-99 m 赤血球による末梢 RI angiography を施行し，ベッドを移動させる方式にて 1 回の ファーストパス法で腹部から下肢動脈領域までの広範囲 な血行イメージを作成した，特注ベッドに被検者を背卧 位にし, 腹部大動脈流入後より手動で体軸方向に移動さ せた. 1 フレーム1.5秒で30秒間ガンマイメージャで撮像 と同時にコンピュータで 0.5 秒，64×64マトリックスで 30〜40秒間データ収集した。画像処理を行い, 全体イメ ージを作成した．動脈走行速度の左右差・狭窄・閉塞の 部位・範囲が観察できた。現在最大の有効視野 $51 \mathrm{~cm} て ゙$ も 2 回の検查が必要な範囲を本法は 1 回で済み, 被検者 の被曝軽減ができ，臨床上有用な方法であると考える。
139. ${ }^{99 m}$ TC-DTPA を用いた食道運機能検血法 東海大学病院放射線診療センター ○福田利雄・村上 剛・宮䆓義和 梅本 亨・新田祐司

食道疾患の形態検查法は数多いが，その運動機能を評 価する方法としては一般に内圧検㚗が用いられているに 過ぎず簡便性という点で問題が残る. 今回われわれは RI を用いて非侵裝的に食道運動機能を定量的に分析する簡 便な方法について報告した。

処理結果より，作製した time activity curve およびフ アンクショナルイメージのパターン認識による異常の有 無の判定が可能であり，また定量的に算出したパラメ一 夕を疾患別に解析した場合に明らかな有意差が認められ た，本法は食道運動機能を評価する上でスクリーニング 検㚗として，また術前術後の治療効果の判定および薬剂 効果の判定に使用できる有用な検查方法である。

140. Dual Isotope Scanによる術後消化管機能の評価 帝京大学医学部付属病院放射線部

○新尾泰男・河淮雅宏・相川恵美子

消化管の外科的手術例に抢ける消化管残存機能を確認 するため, 胆道・消化管 dula isotope scan を実施した. それにより術式の評価が可能であるかを検討した。、ぺ トグラム，ガストログラム単一では評洒し難いが，局所 腸管内の RI 移行を考慮し, 動態表示をすることにより， 一部統計的に術式間の有意差を認めた．検討例中 $18 \% に$ 胆汁の胃内逆流を認めたことからその定量の試みを行っ た、肝・胃 TAC (time actvity curve) の積分面積比と 積分 TACの傾きから逆流量, 流入・出速度の index を求 めた。これにより逆流症例の経過観察に有用であった。

\section{座長集約}

演題137は，慢性下肢動脈閉塞症に対して RI angiographyによる術前, 術後の定栔的評洒を行い, R-MTT が自覚症状とよく相関し再現性もよく，有用な指標であ ると報告した。

筫問（埼玉医大：伊勢谷）自賞症状のとらえ方は？ 答 歩けるか歩けないかである。

筫問（座長） 高分解能タイプのコリメータを用いた ため，カウント不足と思えるが？

答 左右比較しているので，お互いに低いもの同志で 評洒できる。

演題138は，下肢動脈閉塞症に対して RI angiography を施行し，ベッドスライド方式にめ広範囲の first pass イメージを得て, コンピュータにて全体イメージを作成 し，有用であると報告した。 